UNIO - EU Law Jounal. Vol. 2, No. 2, June 2016, pp 20-38.

®2016 Centre of Studies in European Union Law

School of Law - University of Minho

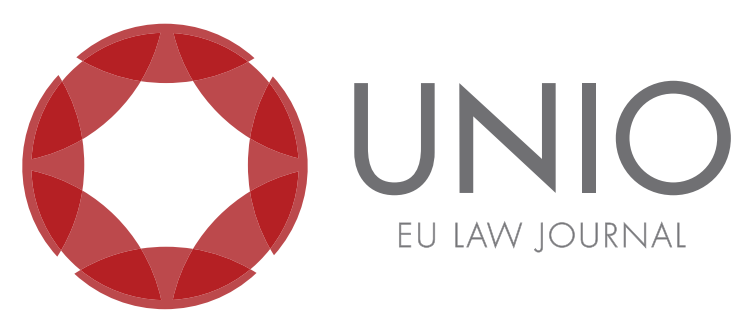

\title{
Right to collective action in cross-border employment contexts: a fundamental social right not yet covered by EU private international law
}

\section{Cinzia Peraro*}

ABSTRACT: The purpose of this article is to describe the right to collective action in crossborder employment contexts, recognised as a fundamental social right at the national and European levels. On the one hand, some national Constitutional Courts, such as the Portuguese and Italian ones, have dealt with social rights and the economic crisis, and have clearly stressed the prevalence of constitutional social rights over austerity measures. On the other hand, Council of Europe documents and European Union law recognise social rights, but they do not offer a proper means of protection. The European Court of Justice case-law shows a complex interrelation between social rights and economic freedoms. The main issue concerns the existing EU private international law on collective action, which has led to an inconsistent system. A new European collective action framework could be a possible solution to effectively guarantee fundamental social rights.

KEYWORDS: collective action - fundamental social rights - Portuguese and Italian Constitutional Courts - EU private international law.

\footnotetext{
* PhD student in European Union Law in the Law Department of the University of Verona (Italy).

The author is deeply thankful to Professor Alessandra Silveira for her kindness and availability and for hosting her at the "Centro de Estudos em Direito da União Europeia - CEDU" of the University of Minho, where she conducted research from January to February 2016.
} 


\section{Right to collective action in cross-border employment con- texts as a fundamental social right}

Fundamental rights comprise social and employment rights, and they are mostly referenced in international human rights documents and national Constitutions. Social rights enable citizens to demand services and assistance (regarding the right to health, the right to education, social security rights, etc.) from the State, and in contrast, envisage obligations for the States, materialised by means of State measures or direct actions. In employment contexts, such rights include, for instance, the right to collective or industrial action, and to collective bargaining. In particular, industrial actions, including sympathy actions and blockades, strikes, lockouts and so on, are the usual means of achieving coverage for weak parties. All such rights are covered by domestic laws, which may differ from one State to another. The issue analysed in this article regards collective action in cross-border employment contexts, a discipline that has been left to national legislation and its implementation to domestic courts. With regard to the Member States of the European Union (EU), it seems clear that there are different provisions and different parameters to evaluate the legitimacy of industrial action. Even considering EU law, it is not possible to find specific rules governing collective action (or redress).

This paper aims to illustrate the recognition of fundamental social rights, particularly the right to collective action, in international and European instruments, and to point out the protection offered at the national level and in Europe, with particular regard to EU law. In the EU Member States, there is no uniformity between the national laws concerning the procedural aspects and the criteria for the legitimacy of collective action. Indeed, the main problems arise in cross-border contexts. EU law and private international law rules, mainly on the applicable law and jurisdiction, do not provide a consistent legal framework. An evaluation of existing EU private international law is carried out in order to reflect on the necessity of specific EU legislation aimed at guaranteeing the recognised fundamental social rights. ${ }^{1}$

First, it is appropriate to provide the notion of collective action contained in the 2013 Communication of the Commission, which states that it is:

a procedural mechanism that allows, for reasons of procedural economy and/or efficiency of enforcement, many similar legal claims to be bundled into a single court action. Collective redress facilitates access to justice in particular in cases where the individual damage is so low that potential claimants would not think it worth pursuing an individual claim. It also strengthens the negotiating power of potential claimants and contributes to the efficient administration of justice, by avoiding numerous proceedings concerning claims resulting from the same infringement of law. ${ }^{2}$

This procedural mechanism is deemed to be a means of protection favouring weak parties, even those organised in trade unions for employment issues, who are

\footnotetext{
${ }^{1}$ See infra, para. 4.

${ }^{2}$ European Commission, Communication from the Commission to the European Parliament, the Council, the European Economic and Social Committee and the Committee of the Regions "Towards a European Horizontal Framework for Collective Redress”, COM(2013)401 final, 11 June 2013, 4, http://eur-lex.europa.eu/legal-content/EN/TXT/?qid=1455276612525\&uri=CELEX:52013DC0401.
} 
asserting claims for their rights to be respected and observed, and for the defence of their economic and social interests.

In general, the right to strike has a constitutional basis in many States, as an individual fundamental right to be exercised collectively. A strike is a form of protest considered by the workers themselves as the most effective means to achieve their desired goal. It can be freely exercised, without any prior procedural requirements and without any consequences to individual employment contracts. ${ }^{3}$

There are various international legal bases for the right to collective activities, including the right to strike, such as the 1966 International Covenant on Economic, Social and Cultural Rights, ${ }^{4}$ the ILO Conventions No. $87^{5}$ and No. 98, ${ }^{6}$ the 1950 European Convention of Human Rights (hereinafter 'ECHR'), ${ }^{7}$ the 1989 Community Charter of Fundamental Social Rights of Workers, ${ }^{8}$ the 1961 (then 1996) European Social Charter (hereinafter 'ESC') 9 and the 2000 (then 2007) EU Charter of Fundamental Rights (hereinafter 'EU Charter'). ${ }^{10}$ In those provisions, each State party (or Member) is deemed to undertake steps using the maximum of its available resources or by all appropriate means, with a view to progressively achieving the full realisation of the rights, and it must comply with these obligations.

EU law, primarily the European Court of Justice (ECJ) case-law, expressly recalls international and European instruments in order to endorse their objectives and purposes, respectively, in regulating and applying laws in the field of fundamental social rights.

For instance, Article 28 of the EU Charter clearly provides a list of rights: It contains social rights, such as the freedom of association, the right to strike, collective negotiation agreements for workers, participation in government and job security, as well as classical rights. The right to exercise collective industrial action can be utilised to achieve collective labour agreements offering better employment conditions than workers could achieve individually. In other words, trade unions, whose freedom of organisation is guaranteed, must be given the right to effectively act for workers. Thus, the right to bargain for collective agreements, strengthened by industrial action, is decisive for such effective action. Nevertheless, Article 28 states that rights must be safeguarded in accordance with Union law and with national laws and practices.

On the one hand, it is clear that not only procedural, but also substantive, national rules must be observed, since the European Union does not have exclusive competence in this field. ${ }^{11}$ On the other hand, EU law, including EU objectives, values and purposes, must be considered. At this point, it is necessary to mention

\footnotetext{
${ }^{3}$ Federico Fabbrini, "Europe in Need of a New Deal: On Federalism, Free Market and the Right to Strike", in Georgetown Tournal of International Law, 43, 2012, spec. 1185-86, available at SSRN http:// ssrn.com/abstract $=2029145$.

${ }^{4}$ See Article 8.

5 "Convention concerning Freedom of Association and Protection of the Right to Organise", adopted in San Francisco on 9 July 1948, 31st ILC session, and entered into force on 4 July 1950.

6 "Convention concerning the Application of the Principles of the Right to Organise and to Bargain Collectively", adopted in Geneva on 1 July 1949, 32nd ILC session, and entered into force on 18 July 1951.

${ }^{7}$ See Article 11.

${ }^{8}$ See Article 13.

${ }^{9}$ See Article 6.

${ }^{10}$ See Article 28.

${ }^{11}$ See Article 153 TFEU and infra, para. 3.
} 
the two decisions of the ECJ Grand Chamber, Viking and Laval. ${ }^{12}$ The Court held that the right to strike is a fundamental right of the EU constitutional order, but it recognised the need to balance workers' rights with economic freedoms. This means that it has extended EU free movement principles in ways that allow employers to prevent or penalise what would otherwise be regarded domestically as permissible industrial action and that compromise the right to strike. ${ }^{13}$

In any case, the last word is left to the national judges.

\section{Protection of social rights at the national level}

The right to strike, as a social collective action right, is legally recognised in some of the Constitutions of the Member States, but it is mainly considered by their Constitutional Courts. A short analysis of the Portuguese and Italian contexts is included here in order to show the way in which social rights (in general, without specific reference to collective action) are taken into account, and the challenges and obstacles that their protection may encounter. Indeed, both the Italian (Corte costiturionale) and Portuguese (Tribunal Constitucional) Constitutional Courts have addressed social rights protection in some of their recent judgements, which have been delivered in the context of the economic crisis.

In general, judges apply constitutional principles with the aim of fully and effectively pursuing a high level of protection for constitutional rights. The balance between fundamental rights and economic measures has been implemented by the ECJ with reference to fundamental economic freedoms as pillars of EU law. Nevertheless, one could note that EU law clearly refers to the common constitutional traditions of the Member States, ${ }^{14}$ so the ECJ should also probably take national values into account. The finding of the ECJ, which recognised the economic freedoms as prevailing over social rights, appears not to have been followed by (some) national judges. It is, however, important to remember that, in social and employment contexts, the EU does not have an exclusive competence. Therefore, a dialogue between the national and European judges could be a viable way to find an appropriate legal basis to develop a new legislative act addressing cross-border employment disputes. After all, the EU should pursue the protection of fundamental social rights as part of the general principals of EU law.

Broadly speaking, both the Italian and Portuguese Constitutional Courts have considered the protection of social rights in the current economic context dealing with austerity measures (EU-recommended), which have involved substantial cuts in their social provisions.

The Tribunal Constitucional, in its judgement No. 187 of 5 April $2013,{ }^{15}$ declared the unconstitutionality of some of the austerity measures, in particular, those on

\footnotetext{
${ }^{12}$ See infra, para. 3.

${ }^{13}$ Tonia Novitz, “The Internationally Recognized Right to Strike: A Past, Present and Future Basis upon Which to Evaluate Remedies for Unlawful Collective Action?”, in International Journal of Comparative Labour Law and Industrial Relations, 30, No. 3, 2014, 357-379.

${ }^{14}$ See Article 6, 3 TEU.

${ }^{15}$ Available at http://www.tribunalconstitucional.pt/tc/acordaos/20130187.html.
} 
budgetary cuts. ${ }^{16}$ The 2015 Country Report on Portugal ${ }^{17}$ includes an overview of the relevant measures. ${ }^{18}$ Moreover, it analyses the right to work: It "has probably been the most affected fundamental right in the context of the economic crisis. It has been affected by the crisis itself ([which] led to a significant rise of unemployment) and by austerity measures. These measures included pay-cuts, reduction[s] of severance payments and increase[s] in working hours without additional pay." 19

The Portuguese Constitutional Court judgement No. 187 of 2013 concerned the suspension of holiday pay, which it declared unconstitutional as a violation of the principle of equality. The Court has stated that the international and European obligations had a constitutional legal basis, but that they should not impose legislative measures that lead to the violation, not only of equality and proportionality principles, but also of human dignity. ${ }^{20}$ Constitutional law doctrine has deemed this case to be a condemnation of the violation of constitutional rights in relation to the EU agreement (the 2011 Economic Adjustment Programme ${ }^{21}$ implemented by the national provisions. ${ }^{22}$

The Tribunal do Trabalho do Porto, which applied to the ECJ with a reference for a preliminary ruling, claimed respect for EU law. ${ }^{23}$ The Portuguese judges asked for an interpretation of Articles 20,21(1) and 31(1) of the EU Charter of Fundamental Rights in a case dealing with national legislation that provides for salary reductions for certain public sector workers. The ECJ stated that it "clearly lacks jurisdiction with regard to the request", because EU law was not involved. ${ }^{24}$ Some considered the request to be an expression of a "European constitutionality issue", ${ }^{25}$ in which

${ }^{16}$ For some comments, see Miguel Nogueira de Brito and Luís Pereira Coutinho, "A igualdade proporcional, novo modelo no controlo do princípio da igualdade?: comentário ao Acórdão do Tribunal Constitucional no 187/2013", in Direito \& Política / Law \& Politics, Loures No. 4, Jul.-Out. 2013, 182-191; Ravi Afonso Pereira, "Igualdade e proporcionalidade: um comentário às decisões do Tribunal Constitucional de Portugal sobre cortes salariais no sector público", in Revista Española de Derecho Constitucional, número 98, Mayo/Agosto 2013, http://www.cepc.gob.es/en/publications/ journals; Vitalino Canas, "Constituição prima facie: igualdade, proporcionalidade, confiança (aplicados ao "corte" de pensões)", in Número 1, Janeiro 2014, http://e-publica.pt/constituicaoprimafacie. html; Jorge Reis Novais, "O direito fundamental à pensão de reforma em situação de emergência financeira”, Número 1, Janeiro 2014, http://e-publica.pt/odireitofundamentalpensao.html.

${ }^{17}$ Mariana Rodrigues Canotilho, "The Impact of the Crisis on Fundamental Rights across Member States of the EU Country Report on Portugal”, Study for the LIBE Committee, European Parliament, Brussels, February 2015, http://www.europarl.europa.eu/studies. For an overview, see also Isabel Távora and Pilar González, "Chapter 5 - The Reform of Joint Regulation and Labour Market Policy during the Current Crisis: National Report on Portugal (EN)", in Joint Regulation and Labour Market Policy in Europe during the Crisis, Aristea Koukiadaki et al. (eds), 2016, http://www.etui.org/ Publications2/Books/Joint-regulation-and-labour-market-policy-in-Europe-during-the-crisis.

${ }^{18}$ Canotilho, "The Impact," $16 \mathrm{ff}$.

${ }^{19}$ Ibid., 34.

${ }^{20}$ Daniele Butturini, "Portogallo: le norme nazionali imposte dall'austerità europea di fronte al giudizio di costituzionalità”, 30 May 2013, http://www.forumcostituzionale.it.

${ }^{21}$ More info at http://ec.europa.eu/economy finance/assistance eu $\mathrm{ms} /$ portugal/index en.htm.

${ }^{22}$ Butturini, "Portogallo," 26.

${ }^{23}$ Request for a preliminary ruling from the Tribunal do Trabalho do Porto (Portugal), made by decision of 6 January 2012, lodged on 8 March 2012, Case C-128/12.

${ }^{24}$ See ECJ (Sixth Chamber), Order of 7 March 2013, Case C-128/12, Sindicato dos Bancários do Norte e altri v. BPN - Banco Portuquês de Negócios SA, http://curia.europa.eu/juris/document/document.js $\underline{\mathrm{f}}$ ?text $=\& \mathrm{docid}=135145 \&$ pageIndex $=0 \&$ doclang $=\mathrm{PT} \& \operatorname{mode}=1 \mathrm{st} \& \operatorname{dir}=\& \mathrm{occ}=$ first $\&$ part $=1 \& \mathrm{c}$ $\mathrm{id}=917597$.

${ }^{25}$ Carmela Salazar, "Crisi economica e diritti fondamentali - Relazione al XXVIII Convegno annuale dell'AIC”, 11 October 2013, http://www.rivistaaic.it/relazione-al-xxviii-convegno-annuale- 
the Portuguese judges searched for a European legal basis to declare the national legislation at stake to be inadmissible. They believed that the domestic measures were contrary to the principles of equality and non-discrimination, as well as to the right to fair and just working conditions.

Again with reference to Portuguese austerity measures, the European Court of Human Rights (ECtHR) dealt with the case Da Conceição Mateus and Lino Jesus Santos Januário v. Portugal. ${ }^{26}$ The case concerned the payment of the applicants' public sector pensions, which were reduced in 2012 because of cuts to Portuguese government spending. The Court examined the compatibility of the reductions of the applicants' pension payments with Article 1 of Protocol No. 1 (protection of property). The Court held that the pension reductions had been a proportionate restriction on the applicants' right to protection of property. In light of the exceptional financial problems that Portugal faced at the time, and given the limited and temporary nature of the pension cuts, the Portuguese government had struck a fair balance between the interests of the general public and the protection of the applicants' individual right to their pension payments.

It is clear that the economic crisis and the urgent national measures may affect individual social rights negatively, as in the abovementioned circumstances. Recourse before the European Courts, i.e. the ECJ or the ECtHR, has been sought with the aim of pursuing European protection of social rights. Both Courts, however, have rejected such requests, either because of their incompetence or because of the States' margin of appreciation.

On the one side, the ECJ held that "é jurisprudência assente que as exigências que decorrem da proteção dos direitos fundamentais vinculam os Estados Membros sempre que estes sejam chamados a aplicar o direito da União. Todavia, importa recordar que, nos termos do artigo $51, \mathrm{n} .{ }^{\circ} 1$, da Carta, as disposições desta têm por destinatários "os Estados Membros, apenas quando apliquem o direito da União", e que, por força do artigo 6, n. $^{\circ} 1$, TUE, que atribui valor vinculativo à Carta, esta não cria nenhuma competência nova para a União e não altera as competências desta. Ora, não obstante as dúvidas expressas pelo órgão jurisdicional de reenvio quanto à conformidade da Lei do Orçamento de Estado para 2011 com os princípios e os objetivos consagrados pelos Tratados, a decisão de reenvio não contém nenhum elemento concreto que permita considerar que a referida lei se destina a aplicar o direito da União. Não ficou assim demonstrada a competência do Tribunal de Justiça para responder ao presente pedido de decisão prejudicial. Nestas circunstâncias, há que concluir que o Tribunal de Justiça é manifestamente incompetente para conhecer do pedido de decisão prejudicial apresentado pelo Tribunal do Trabalho do Porto.”27

On the other side, the ECtHR stated that the margin of appreciation "is usually allowed to the State under the Convention when it comes to general measures of economic or social policy. Because of their direct knowledge of their society and its needs, the national authorities are in principle better placed than the international judge to appreciate what is in the public interest on social or economic grounds, and the Court will generally respect the legislature's policy choice unless it is "manifestly

dell-aic-crisi-economica-e-diritti-fondamentali.html.

${ }^{26}$ ECtHR (Second Section), Decision of 8 October 2013, Applications No. 62235/12 and No. 57725/12, http://hudoc.echr.coe.int/eng?i=001-128106.

${ }^{27}$ Judgment Sindicato, paras. 10 - 14 (this judgment is only available in Portuguese and French). 
without reasonable foundation." 28

Some of the economic and financial measures that were produced to tackle the economic crisis have been the object of some important judgements of the Corte costiturionale. Among them, sentence No. 310 of 10 December $2013^{29}$ concerned the freezing of the salaries of university teachers. The Court held that, by virtue of the reasonableness principle, the development of such measures must be considered in the current economic, legal, national and European contexts. ${ }^{30}$

Italy has enacted a number of legislative and other measures related to the crisis, which are summarised in the 2015 Country Report on Italy. ${ }^{31}$ Among them, in Law 92/2012 - the so-called Legge Fornero, ${ }^{32}$ named after the then Minister of Employment - the main objectives were more equal protection of workers, regardless of the type of employment contract, and more flexibility in hiring and dismissing workers. ${ }^{33}$ An Italian trade union (CGIL) "submitted a complaint to the European Commission denouncing that the Reform infringes EU law (i.e. Council Directive 1999/70/EC of 28 June 1999 concerning the framework agreement on fixed-term work) because, among other things, it eliminates the requirement for a justification to use short-term employment contracts and, by so doing, 'translates into a wide broadening of the unjustified use of short-term contracts'. Similar allegations were raised to the ECJ in the case Mascolo $^{34}$ concerning the use of short-term contracts to meet essentially permanent needs in the Italian public education sector." ${ }^{35}$ The ECJ held that

Clause 5(1) of the framework agreement on fixed-term work concluded on 18 March 1999, which is set out in the annex to Council Directive 1999/70/EC of 28 June 1999 concerning the framework agreement on fixed-term work concluded by ETUC, UNICE and CEEP, must be interpreted as precluding national legislation, such as that at issue in the main proceedings, which, pending the completion of competitive selection procedures for the recruitment of tenured staff of schools administered by the State, authorises the renewal of fixed-term employment contracts to fill posts of teachers and administrative, technical and auxiliary staff that are vacant and unfilled without stating a definite period for the completion of those procedures and while excluding any possibility, for those teachers

\footnotetext{
${ }^{28}$ ECtHR, Decision of 8 October 2013, para. 22.

${ }^{29}$ Available at http://www.cortecostituzionale.it/actionPronuncia.do.

${ }^{30}$ Italian Constitutional Court, sentence No. 310 of 10 December 2013, para. 13.4.

${ }^{31}$ Giuseppe Nastasi and Giuseppe Palmisano, "The Impact of the Crisis on Fundamental Rights across Member States of the EU Country Report on Portugal", Study for the LIBE Committee, European Parliament, Brussels, February 2015, 17 ff., http://www.europarl.europa.eu/studies. For an overview of the reforms, see also Sabrina Colombo and Ida Regalia, "Chapter 4 - The Reform and Impact of Joint Regulation and Labour Market Policy during the Current Crisis: Italy (EN)", in Joint Regulation and Labour Market Policy in Europe during the Crisis, Aristea Koukiadaki et al. (eds), 2016, http://www.etui.org/ Publications2/Books/Joint-regulation-and-labour-market-policy-in-Europe-during-the-crisis.

${ }^{32}$ For a critical comment, see Gabriele Piazza and Martin Myant (ETUI), "Italy's Labour Market Reforms of 2012: Did They Reduce Unemployment?”, 2016, http://www.etui.org/Publications2/ Working-Papers/Italy-s-labour-market-reforms-of-2012-did-they-reduce-unemployment.

${ }^{33}$ Nastasi and Palmisano, "The Impact," $52 \mathrm{ff}$.

${ }^{34}$ ECI (Third Chamber), 26 November 2014, Judgment Mascolo, Case C-22/13 and others, http:// curia.europa.eu/juris/document/document.jsf?text $=\&$ docid $=161282 \&$ pageIndex $=0 \&$ doclang $=\mathrm{EN}$ $\underline{\text { \&mode }}=1$ st \&dir $=\& o c c=$ first $\&$ part $=1 \&$ cid $=221997$.

${ }^{35}$ Nastasi and Palmisano, “The Impact," 57 ff.
} 
and staff, of obtaining compensation for any damage suffered on account of such a renewal. It appears, subject to the checks to be carried out by the referring courts, that such legislation, first, does not permit objective and transparent criteria to be identified in order to verify whether the renewal of those contracts actually responds to a genuine need, is capable of achieving the objective pursued and is necessary for that purpose, and second, does not contain any other measure intended to prevent and punish the misuse of successive fixed-term employment contracts. ${ }^{36}$

Balancing social rights with economic measures is the core issue. National courts have claimed respect for the fundamental rights provided for in the EU Charter in relation to the restrictive measures adopted by the States to tackle the economic crisis. As pointed out by the ECJ, the Member States must respect fundamental rights whenever they are called upon to apply EU law, as stated by Article 51, 1 of the EU Charter. By contrast national measures imposing restrictions on social rights, such as those in the cases before the Portuguese and Italian Constitutional Courts, should not fall within EU law, because it is provided that under Article 5 TFEU the Member States shall coordinate the economic policies within the EU. Thus, the measures adopted by them in the field of economic policies should not be subject to EU general principles.

A similar issue has arisen according to the ECJ case-law on EU competence in economic governance and monetary matters. ${ }^{37}$ The Court stated that Member States are not implementing EU law, within the meaning of Article 51, 1 of the EU Charter, when they establish a stability mechanism such as the ESM (European stability mechanism, under Article 136, 3 TFEU, the insertion of which is provided for by Article 1 of Decision 2011/199). In particular, it observed that the EU and FEU Treaties do not confer any specific power on the Union to establish the ESM and its creation is not capable of affecting the exclusive competence held by the Union under Article 3, 1, c TFEU in the area of monetary policy for the Member States whose currency is the euro. So, ESM and national measures adopted as a result of it are not included in the EU law scope. It follows that Member States are not obliged to respect EU Charter' rights and they are not subject to ECJ jurisdiction. However, such statement has been criticised for its inconsistency. In the field of Economic and Monetary Union (EMU) the Member States and institutions when adopting economic or monetary measures are required to comply with the Charter, but this does not occur when the same or similar measures are adopted in the field of ESM. ${ }^{38}$

Moving ahead to collective action in cross-border contexts, one could wonder if such action, i.e. a strike or another industrial action, may be legitimately exercised with the aim of obtaining respect for social rights. Indeed, international, European and national instruments have recognised the right to collective redress as a fundamental social right. Thus, the remaining questions concern the most suitable solution for guarantying social rights in a period of economic crisis, as well as the (constitutional) rights that should be guaranteed. Because of all of the above considerations, the choice between the public interest and the protection of social

\footnotetext{
${ }^{36}$ Judgment Mascolo, para. 120.

${ }^{37}$ See, for instance, ECJ (Full Court), Case C-370/12, 27 November 2012, Judgment Pringle.

${ }^{38}$ See Judgment Sindicato, para. 11. For a comment, see Francesco Munari, "Da Pringle a Gauweiler: i tormentati anni dell'unione monetaria e i loro effetti sull'ordinamento giuridico europeo," Il Diritto dell'Unione europea, No. 4, 2015, 741 ff.
} 
rights, both constitutionally provided, is left to national legislators or judges, bearing in mind that restrictions can be justified only when they are necessary to uphold other equivalent constitutional values. ${ }^{39}$

\section{Protection of social rights in Europe}

Given the recognition of social rights in Europe, as mentioned above with specific regard to the Council of Europe's instruments (the European Convention on Human Rights and the European Social Charter) and European Union law (EU Treaties and the EU Charter of Fundamental Rights), their protection is a primary objective. On the one side, the EU needs to address economic and social divergences, which have been widening. On the other side, the difficulty in overcoming the crisis is largely due to the weaknesses in the current monetary union model, which gives national governments only one option for adjusting their economies: cost-cutting and ever-greater flexibility in the labour markets. ${ }^{40}$

Within the political debate about how to tackle the economic needs and social challenges, the European Commission presented the 2013 Communication entitled "Strengthening the social dimension of the economic and monetary union," ${ }^{41}$ in which it "proposes a number of initiatives to strengthen the social dimension of EMU with a particular focus on three points: reinforced surveillance of employment and social challenges and policy coordination; enhanced solidarity and action on employment and labour mobility; strengthened social dialogue." ${ }^{42}$ This action falls within the scope of the Europe 2020 Strategy for smart, sustainable and inclusive growth, which places social policy at the core of the EU's economic plan. ${ }^{43}$ Following the Communication, the European Parliament, in its 2013 Resolution, ${ }^{44}$

urges that social considerations be placed at the core of European integration and mainstreamed into all EU policies and initiatives; considers that the social dimension should be a reconciliation/trade-off factor in terms of 'benchlearning'; notes that the purpose of the social dimension of the EMU is to provide social security and a sufficient living standard for current and future generations; considers it important, therefore, for EU citizens to see that their Union is capable of promoting social progress. ${ }^{45}$

\footnotetext{
${ }^{39}$ Fabbrini, "Europe in Need," 1187.

${ }^{40}$ See more at: http://www.easpd.eu/en/content/commission-proposes-social-scoreboard-deepensocial-dimension-emu\#sthash.ouhgd0D6.dpuf.

${ }^{41}$ European Commission, "Communication from the Commission to the European Parliament and the Council, Strengthening the social dimension of the economic and monetary union", COM(2013)690 final, 2 October 2013, http://eur-lex.europa.eu/legal-content/EN/TXT/?qid=14 54279713587\&uri=CELEX\%3A52013DC0690. Recently recalled by Vice-President Dombrovskis, Speech on February 4, 2015, https://ec.europa.eu/commission/2014-2019/dombrovskis/ announcements/european-parliament-strengthening-social-dimension-emu en.

${ }^{42}$ See $\operatorname{COM}(2013) 690$ final, 1.

${ }^{43}$ Ibid., 2 ff.

${ }^{44}$ European Parliament, Resolution of 21 November 2013 on the Commission communication entitled 'Strengthening the social dimension of the Economic and Monetary Union (EMU)', P7_ TA(2013)0515, http://www.europarl.europa.eu/sides/getDoc.do?pubRef=-//EP//TEXT+TA+P7TA-2013-0515+0+DOC+XML+V0//EN.

${ }^{45}$ P7_TA(2013)0515, paras. 4-6.
} 
It should be noted that employment and social policies fall, very largely, under the national competence of the Member States: Social policy is an area of shared competence between the EU and the Member States (Article 4, 2, b TFEU). Pay, the right of association, the right to strike and the right to impose lock-outs are beyond EU competence (Article 153, 5 TFEU). The harmonisation of national laws in the areas of social exclusion and the modernisation of welfare protection systems are also beyond EU competence, though the EU may coordinate the national laws (Article 153, 1 TFEU). Furthermore, any EU legislation relating to employees' protection against dismissal, the information and consultation of workers, collective representation and the defence of workers' and employers' interests, and the conditions of employment for non-EU nationals, requires unanimity in the Council (Article 153, 2 TFEU). "The absence of a general regulatory authority by the EU over employment conditions and social law is the key point regarding the interrelation of social and labour rights and Internal Market law." ${ }^{46}$

However, ECJ case-law has expanded upon the Treaties. Two decisions are controversial with specific reference to the protection of workers' rights through trade union actions, industrial actions or strikes. In Viking, ${ }^{47}$ the Court found that the rights of workers to associate and take collective action were fundamental rights recognised by the EU legal order. Such collective action may legitimately restrict the right of the establishment of an undertaking that intends to relocate to another Member State, in order to protect the workers of that firm. The restriction should not be disproportionate, and its evaluation is left to the referring court. This ECJ finding demonstrates that "the right of trade unions to exercise their collective fundamental right is very seriously hampered by the application of internal market law." 48

In Laval, ${ }^{49}$ the Court again found that trade unions had been exercising a fundamental right to take collective action, recognised by EU law, but that its practical exercise had led to barriers to inward investment that were disproportionate. The ECJ's reasoning started with the consideration that the provisions on the free movement of services in the TFEU have a horizontal direct effect. "The right of trade unions of a Member State to take collective action by which undertakings established in other Member States may be forced to sign the collective agreement for the building sector is liable to make it less attractive, or more difficult, for such undertakings to carry out construction work in Sweden, and therefore constitutes a restriction on the freedom to provide services within the meaning of Article 49 EC." ${ }^{50}$ Only nondiscriminatory, justified and proportionate industrial action is lawful.

\footnotetext{
46 European Parliament, Study, "EU Social and Labour Rights and EU Internal Market Law", September 2015, 59, http://www.europarl.europa.eu/RegData/etudes/STUD/2015/563457/IPOL STU(2015)563457 EN.pdf:

47 ECJ (Grand Chamber), Case C-438/05, 11 December 2007, Judgment International Transport Workers' Federation and Finnish Seamen's Union v. Viking Line ABP and OÜ Viking Line Eesti, http:// curia.europa.eu/juris/document $/$ document.jsf?text $=\&$ docid $=71495 \&$ pageIndex $=0 \&$ doclang $=$ en $\&$ mode $=1$ st $\&$ dir $=\& o c c=$ first $\&$ part $=1 \& c i d=15635$.

${ }^{48}$ Bruno De Witte, "Balancing of Economic Law and Human Rights by the European Court of Justice", in Human Rights in International Investment Law and Arbitration, P.M. Dupuy et al. (eds), 2009, 206. See Judgment Viking, paras. 44-47 (similarly in Laval, para. 91 ff.).

49 ECJ (Grand Chamber), Case C-341/05, 18 December 2007, Laval un Partneri Ltd v. Svenska Byggnadsarbetareförbundet, Svenska Byggnadsarbetareförbundets avdelning 1, Byggettan and Svenska Elek.trikerförbundet, http:// curia.europa.eu/juris/document/document.jsf?docid=71925\&mode=lst\&pa geIndex $=1 \&$ dir $=\& o c c=$ first $\&$ part $=1 \&$ text $=\&$ doclang $=$ EN\&cid $=16415$.

${ }^{50}$ Judgment Laval, para. 99.
} 
In his opinion, Advocate General Mengozzi noted:

Article 49 EC [now Article 56 TFEU] cannot impose obligations on trade unions which might impair the very substance of the right to take collective action. [...] That assessment must, in my view, be extended to a situation where, as would appear to be the case here, the right to take collective action is allowed not only in order to defend the interests of trade union members but also to enable them to pursue legitimate objectives recognised by Community law, such as the protection of workers in general and the fight against social dumping in the Member State concerned. Nevertheless, since that right is not absolute, its exercise must be reconciled with the Community public interest requirement represented by the freedom to provide services in the Community. ${ }^{51}$

Collective action should be a means aimed at the protection of social rights.

One may argue that the ECJ respects the right to collective bargaining, collective action and to strike only within the limits of economic freedom, with a clearly lower value and not as an equivalent fundamental right. In doing so, it adopts a negative approach that is restricted to industrial action taken substantially by host country unions and not by the posted workers. ${ }^{52}$

One author observed the inconsistency in the ECJ's reasoning, because it calls upon national judges to maintain a balance, i.e. to determine if the collective action is proportionate and justified, without a direct decision about the prevalence of one right over another. He noted: "in both cases, the Court uses the term 'balancing', although the impression one gets is that it gave rather more weight to the economic freedoms invoked by the trade unions. A particular quirk of the EU judicial system is that the outcome of the balancing does not always have to be decided by the ECJ itself. The preliminary reference mechanism may create a situation where it is not the international court itself (in this case, the ECJ) that decides on the balance to be struck, in a given case, between economic objectives and human rights, but the national courts where the case originates - albeit under guidance of general guidelines formulated by the ECJ." ${ }^{53}$

Furthermore, following the ECJ's decision, the Swedish Trade Union Confederation (LO) and the Swedish Confederation of Professional Employees (TCO) submitted a complaint $t^{54}$ to the European Committee of Social Rights (ECSR) emphasising that industrial action against a foreign employer is thus forbidden in the 2010 Lex Laval, in violation of Articles 6 and 19 of the ESC and the ILO Convention No. 87. The ILO Committee, in its 2013 Report, had requested that the Swedish Government “ensure that workers' organisations representing foreign

${ }^{51}$ AG Mengozzi, Opinion delivered on 23 May 2007, Case C-341/05, Judgment Laval, paras. 251-252, http:/ / curia.europa.eu/juris / document/document.jsf?docid $=62532 \&$ mode $=1$ st\&pageIndex $=1 \&$ dir $=$ $\underline{\text { \&occ }=\text { first\&part }=1 \& \text { text }=\& \text { doclang }=E N \& c i d=477785}$.

${ }^{52}$ Rudolf Buschmann, "Tensions between Trade Union rights in the EU Charter of Fundamental Rights and the European Convention on Human Rights", January 27, 2015, https:// courtsandcharters2.files.wordpress.com/2015/01/tensions-between-trade-unionrights-in-the-eucharter-of-fundamental-rights-and-the-european-conventionon-human-rights.doc.

${ }^{53}$ De Witte, "Balancing of Economic Law," 206-207.

${ }^{54}$ ECSR, Decision on admissibility and the merits: Swedish Trade Union Confederation (LO) and Swedish Confederation of Professional Employees (TCO) v. Sweden, Complaint No. 85/2012. 
posted workers are not restricted in their rights simply because of the nationality of the enterprise." ${ }^{55}$ After it stated its competence, ${ }^{56}$ the ESCR affirmed that the Swedish legislation "constitutes a disproportionate restriction on the free enjoyment of the right of trade unions to engage in collective action, in so far as it prevents trade unions taking action to improve the employment conditions of posted workers over and beyond the requirements of the above-mentioned conditions." This collective redress has a symbolic value: The trade unions applied to the ESCR to claim respect for international standards, because collective action aimed at protecting social rights is missing in the EU system. ${ }^{57}$

The main assumption of the ECJ must be given attention: "[T] he right to take collective action, including the right to strike, must therefore be recognised as a fundamental right which forms an integral part of the general principles of Community law the observance of which the Court ensures." 58 The Court recognised the existence of a fundamental right to strike in the EU constitutional order. Nevertheless, the express recognition did not lead to enhanced protection of that right. The ECJ designed a balancing test between free movement and social rights that ensures the protection of the right to strike only when industrial action is suitable and proportionate to the achievement of the workers' goal. ${ }^{59}$

Indeed, the Laval and Viking judgements contain references to a number of international treaties to which the Member States are parties, as well as instruments developed by the Member States at the (then) Community level. The international treaties to which the Court referred are the 1961 European Social Charter, to which Art. 136 EC (now Art. 151 TFEU) specifically refers, and the ILO Convention No. 87. At the EU level, the Court referred to the Community Charter of the Fundamental Social Rights of Workers and the EU Charter. ${ }^{60}$ In fact, the Court is entitled to draw inspiration from those instruments for the protection of human rights, as well as from the ECHR, as provided for in Article 6, 2 TEU. The ECJ then added that the exercise of that right may, nonetheless, be subject to certain restrictions in accordance with Community law and national law and practices. ${ }^{61}$

However, the ECJ did not refer to the common constitutional traditions of the Member States in which the right to strike is recognised in either the Laval ruling or the Viking case. It did not derive any substance from those sources. However, in Laval, Advocate General Mengozzi pointed out that "the Court has already emphasised that its principal aim, as is apparent from its preamble, is to 'reaffirm rights as they

\footnotetext{
55 See International Labour Conference, 102 ${ }^{\text {nd }}$ Session, 2013, Report of the Committee of Experts on the Application of Conventions and Recommendations, http://www.ilo.org/ilc/ ILCSessions/102/reports/reports-submitted/WCMS 205472/lang--en/index.htm.

${ }^{56}$ See Complaint No. 85/2012, para. 73.

${ }^{57}$ Silvana Sciarra, "Pluralismo sindacale multilivello nella crisi. Gli orizzonti della Carta sociale europea", in Studi sull'integrazione europea, IX, 2014, 240 ff.

${ }^{58}$ Judgment Viking, para. 44. See Gavin Barrett, "Lawyers, the Question of Whether the European Union is Good for Workers, and How to Help Doom a Referendum on the Lisbon Treaty Without Really Trying", 2009, 40, http://www.um.edu.mt/europeanstudies/books/CD MESA09/pdf/ gbarrett.pdf, who wrote that "the case has actually created at least one benefit for trade unions: the recognition of the right to strike as general principle."

${ }^{59}$ Fabbrini, "Europe in Need", 1201. See also Adam P. McCann, "The CJEU on Trial: Economic Mobility and Social Justice", in European Review of Private Law, 22, No. 5, 2014, available at SSRN: http://ssrn.com/abstract $=2494591$.

${ }^{60}$ Judgment Laval, para. 90 and Viking, para. 43.

${ }^{61}$ Judgment Laval, para. 91 and Viking, para. 44.
} 
result, in particular, from the constitutional traditions and international obligations common to the Member States, the TEU, the ECHR, the Social Charters, and the case-law of the Court ... and of the ECtHR'." ${ }^{\prime 2}$ He then noted that

as regards the constitutional traditions of the Member States, whilst I am not of the view that they must be examined exhaustively, in view of the fact that the EU Charter, although not binding, is principally intended to reaffirm the rights resulting in particular from those traditions, I would nevertheless point out that the constitutional instruments of numerous Member States explicitly protect the right to establish trade unions and the defence of their interests by collective action, the right to strike being, in that connection, the method most regularly referred to. ${ }^{63}$

With regard to the ECHR, the freedom to form trade unions and the right to resort to collective action are provided for in Article 11, relating to the freedom of assembly and of association, of which trade union freedom is merely one special aspect. It does not expressly refer to the right to collective action. Nevertheless, it covers such right through ECtHR case-law. In fact, the Court has held that "strike action is an important method by which trade unions protect their members' interests. It follows that any restriction on the freedom to strike can be justified under Article 11, 2 ECHR only if 'prescribed by law', in pursuance of one or more legitimate aims, and 'necessary in a democratic society' for the achievement of those aims." ${ }^{64}$

In his Concurring Opinion in Hrvatski Liječnički Sindikat v. Croatia, ${ }^{65}$ Judge Pinto de Albuquerque observed: "the right of association of workers includes the following essential elements: the right to form and join a trade union, the prohibition of closed-shop agreements, the right to bargain collectively with the employer and the right for a trade union to seek to persuade the employer to hear what it has to say on behalf of its members. In a democratic society, the ultimate practical "means to persuade the employer to hear" the demands of the workers is obviously strike action. If collective action represents the core of the workers' freedom of association, strike action is the core of the core. Indeed, striking predated both unions and collective bargaining. Thus, the taking of strike action should be accorded the status of an essential element of the Article 11 guarantee."

Within the Council of Europe system, another instrument is of great relevance in the field of social protection. The European Social Charter, enacted in 1961 and revised in 1996, in Article 6, 4, explicitly protects "the right of workers and employers to collective action in case of conflicts of interest, including the right to strike." ${ }^{97}$ The ESC, however, did not include any effective mechanism to enforce this

\footnotetext{
${ }^{62}$ AG Mengozzi, Opinion, Judgment Laval, para. 68.

${ }^{63} \mathrm{Ibid}$., para. 77 and footnote 31-33.

${ }^{64}$ ECtHR (Third Section), 21 April 2009, Application No. 68959/01, Enerji Yap-Yol Sen v. Turkey, para. 25 ff., http://hudoc.echr.coe.int/eng?i=001-92266. See also ECtHR (Fifth Section), 2 October 2014, Application No. 48408/12, Veniamin Tymoshenko and others v. Ukraine, http://hudoc.echr.coe. int/eng? $1=001-146671$.

${ }^{65}$ ECtHR (First Section), 27 November 2014, Application No. 36701/09, Hrvatski Liječnički Sindikat v. Croatia, http://hudoc.echr.coe.int/eng?i=001-148181.

${ }^{66}$ Concurring Opinion of Judge Pinto de Albuquerque, Hrvatski Liječnički Sindikat v. Croatia, para. 8, http://hudoc.echr.coe.int/eng?i=001-148181.

${ }^{67}$ For a comment, see Stein Evju, "The Right to Collective Action under the European Social
} 
right. Compliance by the signatory States is ensured through periodic reviews, and it was not until 1995 that an optional Protocol was adopted to allow a complaint before the European Committee of Social Rights (ECSR). The Committee may also assess the compliance of a national situation with the Charter, including when the transposition of a European Union Directive into domestic law may affect the proper implementation of the Charter. ${ }^{68}$ This is justified on the basis that when the EU Member States agree on binding measures in the form of directives which relate to matters within the scope of the European Social Charter, they should take full account of the commitments they made upon their ratification of the European Social Charter, just as they should all other international instruments to which they are parties. ${ }^{69}$ Ultimately, neither the ECHR nor the ESC offer an effective means to protect the right to strike at the European level. ${ }^{70}$

In this scenario, the recent judgement delivered by the ECJ in the CASTA case, a reference for a preliminary ruling concerning the application of EU general principles in national public activities whose relevant elements are confined to a single Member State, but from which it is nevertheless possible to determine a certain cross-border interest, necessitates reflection. ${ }^{71}$ The Court evaluated the compatibility of Italian legislation authorising regional health authorities to entrust medical transport activities to registered voluntary associations fulfilling the legal requirements, directly and without advertising, by means of reimbursement of the expenditure incurred with EU principles on public health. It recognised that it is a purely internal situation (national transport contracts with voluntary associations) which pursues budgetary and public service purposes. ${ }^{72}$ The Member States are competent in the organisation of their public health and social security systems, and such objectives are taken into consideration by EU law. ${ }^{73}$ The Member States must guarantee the exercise of fundamental freedoms in the area of health care and must not "introduce or maintain unjustified restrictions", "however, in the assessment of compliance with that prohibition, account must be taken of the fact that the health and life of humans rank foremost among the assets or interests protected by the Treaty and it is for the Member States, which have a discretion in the matter, to decide on the degree of protection which they wish to afford to public health and on the way in which that degree of protection is to be achieved (judgement in Azienda sanitaria locale No 5 'Spezzino' and Others, C-113/13, EU:C:2014:2440, para. 56 and the case-law cited)." ${ }^{\prime 74}$ In the case at issue, the Court allowed restrictions on the economic freedoms in the pursuit of EU general principles such as public health, limited only by the prohibition of the abuse of rights. ${ }^{75}$

Charter", in European Labour Law Journal, 2, No. 3, 2011, 196 ff.

${ }^{68}$ See ECSR, Decision on the merits of 23 June 2010, Confédération Générale du Travail (CGT) v. France, Complaint No. 55/2009, paras. 32 - 33.

${ }^{69}$ Ibid.

${ }^{70}$ Fabbrini, "Europe in Need", 1197-1198. However, on Complaint No 85/2012 and its symbolic value, see Sciarra, "Pluralismo sindacale", $240 \mathrm{ff}$.

${ }^{71}$ ECJ (Fifth Chamber), Case C-50/14, 28 January 2016, Consorzio Artigiano Servizio Taxi e Autonoleggio (CASTA) and Others v. Aqienda sanitaria locale di Ciriè, Chivasso e Ivrea (ASL TO4) and Regione Piemonte, para. 42, http://curia.europa.eu/juris/document/document.jsf?text=\&docid=173914\&pageIndex $=$ $\underline{0 \text { \&doclang }}=$ en\&mode $=1$ st\&dir $=$ \&occ $=$ first \&part $=1 \&$ cid $=39385$.

${ }^{72}$ Judgment CASTA, para. 57.

${ }^{73}$ Ibid., paras. $58-59$.

${ }^{74}$ Ibid., para. 60.

${ }^{75}$ Ibid., para. 65. For some considerations, see Davide Diverio, "Il ruolo degli Stati nella definizione 
What if such a solution is (hypothetically) valid in the context of the protection of social rights (such as in the cases before the Italian and Portuguese Courts)? The balance between economic freedoms and social rights should be determined based on some considerations, namely the EU principles in the social context, the lawfulness of the restrictions on economic freedoms, the compatibility of national legislation with EU law, and the national law's objective. In particular, it could be asserted that the protection of social rights may be negatively affected in the case of national legislation that pursues "the objectives of the good of the community and budgetary efficiency on which that system is based." 76

\section{Collective action in EU private international law}

The recognition of the right to collective action in the general category of fundamental social rights does not imply, with certainty, the existence of specific provisions in the EU legal order, but it necessarily indicates that the EU ascribes it some importance. ${ }^{77}$ At present, collective action, in cross-border contexts, faces legal obstacles affecting its effectiveness. ${ }^{78}$ The issue deals with the existing EU private international law, which does not provide for precise dispositions in favour of disputes regarding employees engaged in transnational employment.

As a general principle, employees are deemed in need of protection as weaker contractual parties. ${ }^{79}$ Recital 18 of the Brussels I Recast ${ }^{80}$ states: "[] $]$ n relation to... employment contracts, the weaker party should be protected by rules... more favourable to his interests than the general rules." Similarly, Recital 23 of the Rome I Regulation ${ }^{81}$ provides that "as regards contracts concluded with parties regarded as being weaker, those parties should be protected by conflict-of-law rules that are more favourable to their interests than the general rules." Moreover, Recital 5 of the Posted Workers Directive ${ }^{82}$ reads as follows: "[A]ny such promotion of the transnational provision of services requires a climate of fair competition and measures guaranteeing respect for the rights of workers." Recital 22 then states that "this Directive is without prejudice to the law of the Member States concerning collective action to defend the interests of trades and professions." Unions may organise forms of collective actions other than strikes, but it has been pointed out that the host Member States' unions typically fail to arrive at a sustainable way to

\footnotetext{
del modello sociale europeo", in Studi sullintegrazione europea, No. 3, 2015, $515 \mathrm{ff}$.

${ }^{76}$ Judgment CASTA, para. 63.

${ }^{77}$ Thomas Welin, "The Freedom to Provide Services and the Right to Establishment -V- The Right to Strike. An Analysis of the Laval and Viking Cases", master's thesis, University of Lund, 2009, 19, http://lup.lub.lu.se/student-papers/record/1562914.

${ }^{78}$ In general, see Arnaud Nuyts and Nikitas E. Hatzimihail, Cross-Border Class Actions. The European Way, Munich: Sellier European Law Publishers, 2014.

${ }^{79}$ For a deep analysis of EU private international law on employment, see Uglješa Grušić, The European Private International L aw of Employment, Cambridge: Cambridge University Press, 2015, spec. 7 ff.

${ }^{80}$ Regulation (EU) No 1215/2012 of the European Parliament and of the Council of 12 December 2012 on jurisdiction and the recognition and enforcement of judgements in civil and commercial matters (recast), http://eur-lex.europa.eu/legal-content/EN/ALL/?uri=CELEX\%3A32012R1215.

${ }^{81}$ Regulation (EC) No 593/2008 of the European Parliament and of the Council of 17 June 2008 on the law applicable to contractual obligations (Rome I), http://eur-lex.europa.eu/legal-content/ EN/ALL/?uri=CELEX\%3A32008R0593.

${ }^{82}$ Directive 96/71/EC of the European Parliament and of the Council of 16 December 1996 concerning the posting of workers in the framework of the provision of services, http://eur-lex. europa.eu/legal-content/EN/TXT/?uri=CELEX:31996L0071.
} 
organise and represent posted workers. ${ }^{83}$

In this legal framework, the European Commission has suggested two proposals.

The first initiative is the 2012 Proposal for a Council Regulation "on the exercise of the right to take collective action within the context of the freedom of establishment and the freedom to provide services." ${ }^{\text {" }} 4$ This followed the 2010 Monti Report on "a new strategy for the single market," 85 which addressed the question "on a practical ground, [of] whether the Posting of Workers Directive still provides an adequate basis to manage the increasing flow of cross-border temporary secondment of workers, while protecting workers' rights. On a normative ground, the question concerns the place of workers' right to take industrial action within the single market and its status vis-à-vis economic freedoms." ${ }^{\prime 86}$ The 2012 Proposal is thus referred to as the (proposed) Monti II Regulation. In the 2010 Report, after recalling the Laval quartet sentences, the author suggested the introduction of a provision to guarantee the right to strike, affirming that "a "social progress clause" would "immunise" the right of strike, as recognised at [the] national level, from the impact of single market rules."

The goal of the proposed Monti II Regulation was to "lay down the general principles and rules applicable at [the] Union level with respect to the exercise of the fundamental right to take collective action within the context of the freedom of establishment and the freedom to provide services." In the Explanatory Memorandum accompanying its proposal, the Commission stated that the proposed Regulation sought to address the "tensions between the freedoms to provide services and of establishment, and the exercise of fundamental rights such as the right of collective bargaining and the right to industrial action" recognised by the ECJ decisions in Viking and Laval. It deemed the clarification of the status of the right to collective action in cross-border contexts to be necessary. A regulatory intervention at the EU level may be "the most effective and efficient solution to address the specific objective [of] reducing tensions between national industrial relation systems and the freedom to provide services." 87

The Proposal, in its Recitals, recalled the international instruments that provide for the right to take collective action, which is the corollary of the right to collective bargaining, without explicitly referring to the right or freedom to strike. Article 1 contained the so-called 'Monti clause', which confirmed that the draft Regulation would not have affected the right to strike provided by the industrial relations laws of the Member States or their enforcement of collective agreements. It was in line with the text of a similar provision in the Proposal for a Regulation on jurisdiction and the recognition and enforcement of judgements in civil and commercial matters (Brussels I Recast) ${ }^{88}$ but it was later rejected. ${ }^{89}$ Article 2 recognised that situations may arise

\footnotetext{
${ }^{83}$ See Grušić, The European Private International Law, 284.

${ }^{84} \operatorname{COM}(2012) 130$ final, Brussels, 21 March 2012, http://eur-lex.europa.eu/legal-content/EN/TXT L?qid=1454353269393\&uri=CELEX\%3A52012PC0130.

${ }^{85}$ Mario Monti, "Report on a New Strategy for the Single Market", May 9, 2010, http://ec.europa. eu/internal market/strategy/docs/monti report final $10 \quad 052010$ en.pdf.

${ }^{86}$ Ibid., 69.

${ }^{87}$ See $\operatorname{COM}(2012) 130$ final, para. 3.2 on the legal basis of the proposed Regulation.

${ }^{88}$ See Article 85 of the Proposal for a Regulation of the European Parliament and of the Council on jurisdiction and the recognition and enforcement of judgements in civil and commercial matters, COM(2010)748 final, Brussels, 14 December 2010, http://eur-lex.europa.eu/legal-content/EN/TX T/?uri=CELEX:52010PC0748\&qid=1454361458167.

${ }^{89}$ See Jan-Jaap Kuipers, "Schemes of Arrangement and Voluntary Collective Redress: A Gap in the Brussels I Regulation”, in Journal of Private International Law, 8, No. 2, August 2012, 225 ff.
} 
involving cases of conflict in which their exercise may have to be reconciled in accordance with the principle of proportionality in line with the standard practice by the courts and EU case-law. At least, the Proposal seemed to represent a framework for the regulation of the right to strike at the EU level. The Commission withdrew the proposed Regulation after several Member States voiced objections concerning its legal basis, ${ }^{90}$ and it has not made alternative proposals since then.

The Posting of Workers Enforcement Directive was the second act proposed by the Commission, and it was adopted in $2014 .{ }^{91}$ This Directive aims to reconcile the exercise of the freedom to provide cross-border services under Article 56 TFEU with appropriate protection of the rights of workers who are temporarily posted abroad for that purpose. It took into account the issue of how to set the right balance between the trade unions' exercise of their right to take collective action, including the right to strike, and the economic freedoms enshrined in the TFEU, in particular, the freedom of establishment and the freedom to provide services. ${ }^{92}$ Its Article 1.2 contains a subsequent version of the 'Monti clause', which states: "[T]his Directive shall not affect in any way the exercise of fundamental rights as recognised in [the] Member States and at [the] Union level, including the right or freedom to strike or to take other action covered by the specific industrial relations systems in [the] Member States, in accordance with national law and/or practice. Nor does it affect the right to negotiate, conclude and enforce collective agreements and to take collective action in accordance with national law and/or practice." Certain features should be highlighted: the disappearance of the reference to Community/EU law; the mention of the right or freedom to strike; the primacy granted to national law and practices; and the recognition of the protection of the right to strike as part of EU law. ${ }^{93}$

In the EU private international law framework on employment matters, the Rome II Regulation ${ }^{94}$ on the law applicable to non-contractual obligations and the Brussels I Recast Regulation are of interest. In particular, industrial action is considered in Article 9 of Rome II. This conflict of laws rule determines that the applicable law is that of the country where the industrial action is to be taken or has been taken, but it only applies to non-contractual liability. This means that it does not cover the consequences for individual employment contracts, which are governed by

\footnotetext{
${ }^{90}$ On the dismissal, see Federico Fabbrini and Katarzyna Granat, "Yellow Card, but No Foul: The Role of the National Parliaments under the Subsidiarity Protocol and the Commission Proposal for an EU Regulation on the Right to Strike", in Common Market Law Review, No. 50, 2013, 115-144.

${ }^{91}$ Directive 2014/67/EU of the European Parliament and of the Council of 15 May 2014 on the enforcement of Directive 96/71/EC concerning the posting of workers in the framework of the provision of services and amending Regulation (EU) No. 1024/2012 on administrative cooperation through the Internal Market Information System ('the IMI Regulation'), http://eur-lex.europa.eu/ legal-content/EN/TXT/?qid=1454362381352\&uri=CELEX:32014L0067. According to its Article 23, Member States shall transpose it by 18 June 2016.

${ }^{92}$ See Proposal for a Directive of the European Parliament and of the Council on the enforcement of Directive 96/71/EC concerning the posting of workers in the framework of the provision of services, COM(2012)131 final, Brussels, 21 March 2012, http://eur-lex.europa.eu/legal-content/ EN/TXT/?uri=CELEX:52012PC0131\&qid=1454362877075.

${ }_{93}$ Andrea Iossa, "Monti Rules: Immunising Collective Action from Market Dynamics (or Vice Versa?)," October 9, 2012, 6, http://works.bepress.com/andrea iossa/2/.

${ }^{94}$ Regulation (EC) No 864/2007 of the European Parliament and of the Council of 11 July 2007 on the law applicable to non-contractual obligations (Rome II), http://eur-lex.europa.eu/legalcontent/en/TXT/?uri=CELEX:32007R0864.
} 
Article 8. Moreover, Article 9 does not include the place where the illegal industrial action causes harm. ${ }^{95}$

According to Article 7 of the Brussels I Recast, an employee or trade union may be sued in the Member State where the 'harmful event' occurred or may occur. The ECJ has interpreted this as including both the location of the event causing the damage (e.g. industrial action) and the place where the damage occurred (e.g. where the firm allegedly suffered a loss). At present, the competent court is that of the place where the business which engaged the employee is or was situated; instead, the jurisdiction should belong, in the case of an action by an employee against an employer, to the court of the place of business from which the employee receives daily instructions; ${ }^{96}$ as regards industrial action, the forum for disputes, in line with the Rome II Regulation, should be the place where the industrial action is to be or has been taken. ${ }^{97}$

It is clear that there is a discrepancy between the provisions at stake, which may lead to a situation in which a court has to apply the law of another Member State, with the risk of not fully guaranteeing the most favourable solution. ${ }^{98}$ This issue was brought to attention in the 2013 Report of the European Parliament "on improving private international law: jurisdiction rules applicable to employment," 99 after which a Resolution was adopted. ${ }^{100}$ It suggested amending Brussels I to clarify that, in disputes arising from industrial action, the courts of the Member State where the industrial action is to be or has been taken should have jurisdiction. Furthermore, it proposed replacing the 'engaging place of business' clause with a reference to the 'place from where the employee receives day-to-day instructions'. It underlined the importance of ensuring coherence: "[T] he rules on jurisdiction for labour relations disputes need to be aligned with the relevant rules on applicable law." Following this, the European Commission in its response simply noted that specific legislation on industrial action was unnecessary. ${ }^{101}$

\footnotetext{
${ }^{95}$ See, in general, Filip Dorssemont and Aukje van Hoek, "Collective action in Labour Conflicts under the Rome II Regulation (part II)", in European Labour Law Journal, No. 2, 2011, $101 \mathrm{ff}$.

${ }^{96}$ For a deep analysis, see Ruggiero Cafari Panico, "Enhancing Protection For Weaker Parties: Jurisdiction Over Individual Contracts of Employment", in Cross-border Litigation in Europe: The Brussels I Recast Regulation as a Panacea?, Franco Ferrari and Francesca Ragno (eds), Padova: CEDAM, 2015, $41 \mathrm{ff}$.

${ }^{97}$ With reference to the Viking and Laval judgements, see UglješA Grušić, "The Right to Strike Versus Fundamental Economic Freedoms in the English Courts, Again: Hiding Behind The "Public Law Taboo" in Private International Law", in Journal of Private International Law, 9, No. 3, December 2013, $413 \mathrm{ff}$.

${ }^{98}$ On the problem of coordination between EU private international law provisions, see Aukje A.H. van Hoek, "Private International Law: An Appropriate Means to Regulate Transnational Employment in the European Union?”, in Erasmus Law Review, No. 3, November 2014, $157 \mathrm{ff}$.

${ }^{99}$ European Parliament, Committee on Legal Affairs, Rapporteur: Evelyn Regner, Report on "Improving private international law: jurisdiction rules applicable to employment", 20 September 2013, A7-0291/2013 (2013/2023(INI)), http://www.europarl.europa.eu/sides/getDoc. do?pubRef $=-/ / \mathrm{EP} / / \mathrm{TEXT}+\mathrm{REPORT}+\mathrm{A} 7-2013-0291+0+\mathrm{DOC}+\mathrm{XML}+\mathrm{V0} / / \mathrm{EN}$.

${ }^{100}$ European Parliament, Resolution of 8 October 2013 on improving private international law: jurisdiction rules applicable to employment, http://www.europarl.europa.eu/sides/getDoc. do? pubRef=- / /EP / /TEXT+TA+P7-TA-2013-0396+0+DOC+XML+V0//EN.

${ }^{101}$ See Follow up to the European Parliament Resolution on improving private international law: jurisdiction rules applicable to employment, adopted by the Commission on 29 January 2014, http://www.europarl.europa.eu/oeil/popups/ficheprocedure.do?lang=en\&reference $=2013 / 2023 \%$ $28 \mathrm{INI} \% 29 \#$ tab-0.
} 


\section{Concluding remarks}

The Institutions have engaged in many reflections about the legal context of collective action in the EU. The common starting point is the recognition of the fundamental social rights, whose protection constitutes an objective that EU law must pursue. The recent 2015 Study of the European Parliament ${ }^{102}$ stressed the complexity of the interrelation between EU Internal Market law and social and labour rights. It also acknowledged that "effective collective industrial action is a precondition of a functioning system of collective bargaining. However, generally wage levels and levels of employment protection are more favourable for workers where trade union representation is effective, which again depends on the scope for collective industrial action." $" 103$

In the past, other soft law instruments have been adopted in the field of collective action. The European Parliament, in its 2012 Resolution on collective redress, pointed out that "in the European area of justice, citizens and companies must not only enjoy rights but must also be able to enforce those rights effectively and efficiently." 104 Effectiveness was also emphasised by the 2013 Communication of the Commission, which, specifically referring to the general principles of European private international law, underlined that it should work efficiently in practice to ensure the proper coordination of national collective redress procedures in crossborder cases. ${ }^{105}$ From a more procedural point of view, the Commission called upon the Member States to follow its 2013 Recommendation, whose "aim is to facilitate access to justice in relation to violations of rights under Union law and to that end to recommend that all Member States should have collective redress systems at [the] national level that follow the same basic principles throughout the Union, taking into account the legal traditions of the Member States and safeguarding against abuse."106

The need for the regulation, coordination and effective protection of social rights seems to be key concept for the elaboration of a European collective action framework. A legislative response to the critical balance between market integration and national social rights that was struck by the ECJ in Viking and Laval is requested. Revisiting the 'Monti clause' and the Monti II Regulation probably would be useful. A new act should define the means of lawful cross-border industrial action and the procedure to be followed by unions before going on strike. ${ }^{107}$ It should also clearly provide that cross-border collective action in employment contexts is protected by EU law. Indeed, various European Union provisions expressly refer to the international legal instruments on social rights. Ultimately, the European Union will thus have not only an economic, but also a social purpose..$^{108}$

\footnotetext{
${ }^{102}$ European Parliament, Study, EU Social and Labour Rights, 30.

103 Ibid., 31.

104 European Parliament, Resolution of 2 February 2012 on "Towards a Coherent European Approach to Collective Redress" (2011/2089(INI)), http://www.europarl.europa.eu/sides/getDoc. do?pubRef=- $/ /$ EP//TEXT+TA+P7-TA-2012-0021+0+DOC+XML+V0//EN\#def 16.

${ }^{105} \operatorname{COM}(2013) 401$ final, para. 3.7.

106 Commission Recommendation of 11 June 2013 on common principles for injunctive and compensatory collective redress mechanisms in the Member States concerning violations of rights granted under Union Law, http://eur-lex.europa.eu/legal-content/EN/ TXT/?uri=OJ:JOL 2013201 R NS0013.

${ }^{107}$ Fabbrini, "Europe in Need," 1236-1238.

${ }^{108}$ See Judgment Viking, para. 79.
} 